\title{
Public-Private Partnership Evaluation Models: perspectives from the public governance to defend public interests
}

Nyalle Barboza Matos ${ }^{1}$

Andréa de Oliveira Gonçalves ${ }^{2}$

${ }^{1}$ Amazonas State University (UEA), Manaus - AM, Brazil

${ }^{2}$ University of Brasília (UnB), Brasília - DF, Brazil

The widespread use of Public Private Partnerships (PPPs) has resulted in the identification of several issues related to lack of governance and inefficient assessments of the quality of service provided. In this context, the objective of this research is to identify the characteristics and conditions used to implement governance mechanisms that ensure the public interest in existing PPP contracts. Based on previous governance research, this study categorized nine governance mechanisms based on the three principles established by the OECD (2012): Clear and Legitimate Institutional Framework; Rationale for proper VfM assessment and Transparent and Healthy Budget Process. The contribution of this research is to systematize the relevant literature on the subject, clarifying the complexity of these issues and offering new theoretical insights to identify the characteristics and conditions used as Value for Money governance and valuation mechanisms, capable of making a difference in the success and evaluation of PPPs in the public interest aspect.

Keywords: public-private partnerships, public governance, public interest 


\section{Modelos de avaliação de Parcerias Público-Privadas: perspectivas da governança pública para defender o interesse público}

O amplo uso de parcerias público-privadas (PPP) levou à identificação de uma série de questões relacionadas à falta de governança e sobre a qualidade do serviço prestado. Nesse contexto, o objetivo desta pesquisa é identificar as características e as condições utilizadas para implementar mecanismos de governança que garantam o interesse público nos contratos de PPP existentes. Com base em pesquisas anteriores sobre governança, este estudo classificou, de forma integrativa, nove mecanismos de governança com base nos três princípios estabelecidos pela OCDE (2012): estrutura institucional clara e legítima; justificativa fundamentada em VfM; e processo orçamentário transparente e íntegro. A contribuição desta pesquisa é sistematizar a literatura relevante sobre o assunto, esclarecendo a complexidade dessas questões e oferecendo novas ideias teóricas para identificar as características e condições utilizadas como mecanismos de valor e governança do Value for Money, capazes de fazer a diferença no sucesso e na avaliação de PPPs no aspecto de interesse público.

Palavras-chave: parcerias público-privadas, governança pública, interesse público

\section{Modelos de evaluación de las asociaciones público-privadas: perspectivas de la gobernanza pública para defender el interés público}

El uso generalizado de las asociaciones público-privadas (PPP) ha llevado a la identificación de una serie de cuestiones relacionadas con la falta de gobernanza y la calidad del servicio prestado. En este contexto, el objetivo de esta investigación es identificar las características y condiciones utilizadas para implementar mecanismos de gobernanza que garanticen el interés público en los contratos existentes de PPP. Basado en investigaciones previas sobre gobernanza, este estudio clasificó, de manera integradora, nueve mecanismos de gobernanza, con base en los tres principios establecidos por la OCDE (2012): estructura institucional clara y legítima; justificación basada en VfM; proceso presupuestario transparente y saludable. La contribución de esta investigación está en sistematizar la literatura relevante sobre el tema, aclarando la complejidad de estos temas y ofreciendo nuevas ideas teóricas para identificar las características y condiciones utilizadas como valor y mecanismos de gobierno para Value for Money, capaces de marcar una diferencia en el éxito y la evaluación de las PPP en el aspecto del interés público.

Palabras clave: alianzas público-privadas, gobernanza pública, interés público 


\section{Introduction}

Although Public-Private Partnerships (PPP) is not a new concept, there is no consensus in the literature on its definition and is considered a broad term describing the collaborative relationships between public and private actors for the achievement of common goals (TORCHIA et al., 2015). When providing public services or building infrastructure, PPPs should have an appropriate governance structure with mechanisms that ensure the alignment of shared interests across sectors, instituting clear and delimited responsibilities, resources and reorganization defined to always preserve the public interest (SEKHRI et al., 2011). However, these hybrid solutions can be difficult to design and implement due to divergent institutional logics between the public and private sector, whose organizational objectives and cultures are heterogeneous - and often conflicting because as the private sector prioritizes profit, the public sector aims to satisfy the collective needs (TORCHIA \& CALABRO, 2018).

Such conflicting interests between the parties have given rise to several studies that report problems arising from information asymmetry and imbalances in power relations between public and private actors (WARSEN et al., 2018). To alleviate these problems, the literature highlights the relative importance of contractual governance mechanisms and contract incentives (WARSEN et al., 2018). In addition, developing public sector capacity to manage PPP contracts is also considered a key task for project success in all its phases (OSBORNE, 2000).

Contracting a partnership also requires adequate knowledge of contract management and evaluation and institutional development. Knowing how to align public and private interests, establishing appropriate forms of assessment and governance mechanisms is a key issue in turning PPP challenges into opportunities and improving policy formulation and public service delivery - better meeting public needs (OSBORNE, 2000).

In this debate on how to optimize partnership agreements, contributions that address the complexity of these issues and offer new theoretical and practical insights can bridge the gap in the current PPP literature and its required forms of assessment and governance mechanisms (TORCHIAM et al., 2015). Given this gap, the research problem that it proposes to investigate is: What are the governance mechanisms pointed out in the international literature that are necessary to ensure public interest in PPP 
contracts? Given this problem, the purpose of this article is to identify what governance mechanisms are indicated in the literature to ensure the public interest in PPPs' contracts.

The integrative review method used in this research is indicated to result in the advancement of knowledge and theoretical structures, rather than a simple general description of a research area and should preferably generate a new conceptual framework or theory, synthesizing new theoretical perspectives (SNYDER, 2019). Applying this method of review is valid and consistent with the proposal to identify and systematize the mechanisms of governance, bridging the gap on how the governance structures in the public sector can be used to defend the public interest in PPP contracts.

The theoretical support used to defend the need for governance in PPP contracts is based on the Theory of Transaction Costs (TCT), which proposes synthesis and combination of governance mechanisms that interfere in serving the public interest. This theory considers not only the financial performance of the contractual proposal, but aspects that can improve the alignment of partnerships with the public interest. Previous researchers such as Warsen, Klijn and Koppenjan (2019), Maurya and Srivastava (2018) and Benítez- Ávila et al. (2018) discussed the ability of governance mechanisms to improve the financial efficiency of a PPP by surveying and testing contributing variables.

Empirical researchidentified an increasing number of problems with the implementation of PPP projects, including in Brazil (CUTRIM et al., 2017; MAURYA \& SRIVASTAVA, 2018). As a result, in recent years, there has been a proliferation of articles focusing on the characteristics and key issues in the implementation of PPP projects (TORCHIA et al., 2015). The contribution of this research is to organize the relevant literature on the subject, identifying the characteristics and conditions used as governance mechanisms, which, will make a difference in the success and evaluation of PPPs, especially with achieving their social objective.

This article is structured in three sections beyond this introduction: the first will outline the theoretical support of governance in the context of PPPs, which describes the fragility of contractual relations in the light of Transaction Cost Theory, highlighting the importance of governance mechanisms to defend public interest in contracts and avoid possible opportunistic behavior between the parties. The second section sets out the steps taken to carry out the integrative review and categorization of the most relevant mechanisms according to the international literature. Lastly, the third section presents the 
results properly found, divided, and individually discussed according to the governance principles they represent.

\section{Theoretical support for PPPs governance}

The Transaction Cost Theory (WILliamson, 1979) emphasizes the economic importance of creating or selecting governance structures for an individual transaction and reducing the contractual risk. The central idea of the theory is that contracts are constructed and formalized under imperfect conditions and considering information that are asymmetrically distributed between the parties, which can cause opportunistic behavior in managers (WILLIAMSON, 1999).

Another hypothesis that arises by an association of this theory with PPPs is that opportunism in partnerships can reduce performance; increase transaction costs; reduce trust, satisfaction and motivation and increase the likelihood of conflict between the parties (MAURYA \& SRIVASTAVA, 2018). Control of opportunism is known to be an essential dimension for increasing expected performance in an organization, and that control is considered the central objective of governance (WILLIAMSON, 1979).

According to TCT, the nature of contractual transactions differs in terms of uncertainty, frequency and specificity of assets (MAURYA \& SRIVASTAVA, 2018). It is then assumed that governance mechanisms also vary in the same terms, dividing into contractual governance and relational governance. Contractual governance includes rational controls involving qualities such as well-written contracts with sufficient incentives between the parties, detailed transactions on specific investments, monitoring and sanctions (WARSEN et al., 2019). On the other hand, in relational governance, contracts are less defined and less rigid, and transactions are governed by relational norms based on institutional characteristics and trust between the parties (WARSEN et al., 2019).

It is known that the concept of governance in the public sector is a widely used term, but difficult to define in a single point of view. For the purposes of this research, the definition of IFAC (2014), as listed in Figure 1, will be used. Within public governance, the concepts and mechanisms of contractual governance that are cited as capable of reducing opportunistic behavior between the parties and protecting the public interest in contracts will be explored. The relationship between the concepts explored can be seen in Figure 1. 
Figure 1 - Relationship Between the Concepts of Governance and the Defense of the Public Interest

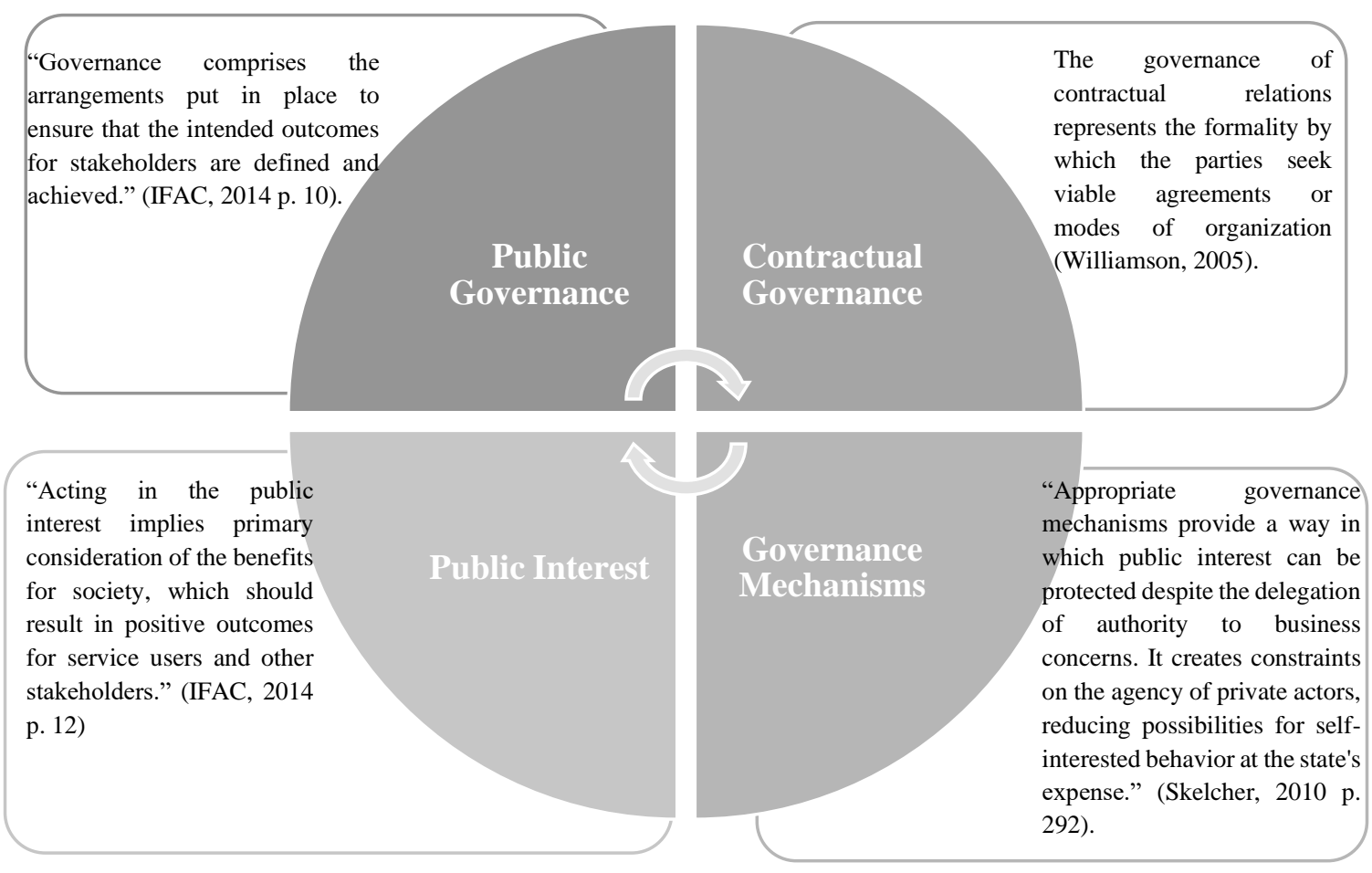

Source: Elaborated by the authors based on the cited authors.

The relationship between the elements are shown in Figure 1. This relationship arises because PPP contracts are said to be incomplete (considering their long-term feature and information asymmetry between the actors), which reinforces the purpose of governance design. Thus, these agreements used to mitigate potential conflicts of interest and opportunism, and enable mutual gain between partners, induces harmony between interests (WILLIAMSON, 1979). By promoting this mitigation of opportunistic behavior, governance plays a key role in reducing transaction costs, filling gaps in agreement contracts between parties, interfering positively on expected performance in the partnership, and defending the democratic principles in the contractual relationship (ZAATO \& HUDON, 2015).

These reasons lead to the conclusion that governance in the public sector, when utilizing an appropriate combination of mechanisms, influences both financial and democratic performance (SKELCHER, 2010). It is assumed that a successful PPP contract is one that was first contracted only when it was proved that the PPP project would bring Value For Money (VfM), representing a net gain. Larger for society when compared to other forms of hiring (GRIMSEY \& LEWIS, 2005). 
In contrast to these expectations, failures of performance of PPPs refer to suspensions of contracts, disputes, lawsuits or technical failures; early termination caused by performance failure in the delivery of public goods of quality and quantity; and postevaluation reports demonstrating that VfM efficiency has not been achieved (XIONG et $a l ., 2018)$. To alleviate these shortcomings, it is necessary to establish governance mechanisms and structures that synchronize all stages from the bidding and contracting phase to subsequent project life cycles (construction, operationalization, monitoring and contract management)(O'NOLAN \& REEVES, 2017). Following this approach, the analysis of the governance structure of a PPP can be seen as a portfolio of mechanisms, which includes both formal and informal elements, which will be defined and discussed throughout this article, following the approach described in the next section (RUFIN \& RIVERA-SANTOS, 2012 ).

\section{Methodology for the construction of the integrative review}

The choice of an integrative review as a literature review method is justified because it is considered the broadest methodological approach to reviews, allowing a complete understanding of the phenomenon analyzed, combining data from the theoretical and empirical literature, and incorporating: definition of concepts, theory review and methodological problem analysis of a particular topic (SouZA et al., 2010).

The methodological design of this research was based on the steps established by Souza, Silva and Carvalho (2010) on how to outline an integrative review. According to the authors, it is necessary to start from a guiding question when selecting a broad sample of the literature on the subject (through electronic bases and robust selection criteria). After selecting the articles on the subject, data is collected on the main findings, a critical analysis is conducted on the studies (relating the main evidence, and the empirical conclusions by quantitative and qualitative methods), the research gaps are analyzed, and finally, the literature review is complete.

Step 1 - Elaboration of the Guiding Question: What are the characteristics and conditions used in the implementation of governance mechanisms that ensure the public interest in PPP contracts?

Step 2 - Sampling the literature: To promote the search, the Web of Science, SciELO and Periódicos Capes databases were used for scientific articles. The terms used 
in the search were: Evaluation of public-private partnerships, Value for Money in publicprivate partnerships, partnerships Governance in public-private. The documents published between 2002 and 2019 in English and Portuguese were considered for analysis.

Step 3 - Data Collection: Based on previous literature reviews (CUI et al., 2018; XIONG et al. 2018), it is known that PPP assessment forms and governance mechanisms are key concepts to include a number of characteristics linked to the success of PPPs in the defense of the public interest. From these two topics, articles that built evaluation methodologies or governance criteria deemed necessary for the proper functioning of a PPP were selected.

In the search for the descriptors defined in step 2 in the selected databases, 1,235 results were found (excluding duplicate references and selecting only the option "scientific articles"). From this number, another filtering through the "advanced search" tool was made, selecting only articles that had any of the keywords in the article title, selecting 63 articles. From this sample, the most relevant themes and contributions relevant to PPP assessment or governance were chosen. Finally, a complete reading list of 21 articles, in addition to databases of the World Bank and the Organization for Economic Co-operation and Development (OECD) to consult books or international guidelines on the theme were selected. Table 1 summarizes the main articles used as the basis of this review, which synthesized and organized governance mechanisms in PPPs. Based on these articles, the main governance categories and mechanisms developed below will be further elaborated on.

Table 1 - Articles From the PPP Databases and Their Main Contributions

\begin{tabular}{|c|c|c|c|}
\hline Article Title & Authors & Journal & Considerations / Thematic \\
\hline $\begin{array}{l}\text { Public - Private } \\
\text { Partnerships in } \\
\text { the Health Care } \\
\text { Sector: } \\
\text { Systematic } \\
\text { Review of the } \\
\text { Literature }\end{array}$ & $\begin{array}{l}\text { TORCHIA } \\
\text { et al., } \\
(2015)\end{array}$ & $\begin{array}{c}\text { Public } \\
\text { Management } \\
\text { Review }\end{array}$ & $\begin{array}{l}\text { Systematic literature review that identified six lines of } \\
\text { research on governance in health sector PPPs: } \\
\text { effectiveness, social and fiscal benefits, public } \\
\text { interest, efficiency, Value for Money, and partner } \\
\text { capacity. }\end{array}$ \\
\hline $\begin{array}{l}\text { Public-Private } \\
\text { Partnerships: } \\
\text { a review of theory } \\
\text { and practice of }\end{array}$ & $\begin{array}{c}\text { LIU et } \\
\text { al. }(2014)\end{array}$ & $\begin{array}{l}\text { Journal of } \\
\text { Productivity } \\
\text { and } \\
\text { Performance } \\
\text { Management }\end{array}$ & $\begin{array}{l}\text { It was found from a theoretical survey } \\
\text { that conventional ex post evaluation is unable to } \\
\text { capture the complexities inherent in PPP project } \\
\text { development processes. Comprehensive and effective } \\
\text { performance measurement requires a process-based }\end{array}$ \\
\hline
\end{tabular}




\begin{tabular}{|c|c|c|c|}
\hline Article Title & Authors & Journal & Considerations / Thematic \\
\hline $\begin{array}{l}\text { performance } \\
\text { measurement }\end{array}$ & & & $\begin{array}{l}\text { life cycle assessment that addresses the complexity of } \\
\text { multiple stakeholders. } \\
\text { Key performance indicators were synthesized into } \\
\text { five categories: } \\
\text { (1) physical characteristics of the project; } \\
\text { (2) financial indicators; } \\
\text { (3) innovation and learning indicators; } \\
\text { (4) stakeholder satisfaction indicators; and } \\
\text { (5) process indicators. }\end{array}$ \\
\hline $\begin{array}{l}\text { Governing public } \\
-\quad \text { private } \\
\text { partnerships: A } \\
\text { systematic review } \\
\text { of case study } \\
\text { literature }\end{array}$ & $\begin{array}{l}\text { XIONG et } \\
\text { al. (2018) }\end{array}$ & $\begin{array}{l}\text { Research } \\
\text { Evaluation }\end{array}$ & $\begin{array}{l}\text { From the literature review, } 21 \text { governance issues were } \\
\text { identified, among which the most important are } \\
\text { cooperation, trust, communication, capacity, risk } \\
\text { allocation and sharing, competition in the bidding } \\
\text { process and transparency. } \\
\text { The main institutional issues are: } \\
\text { authority, legislation, regulation and market opening. } \\
\text { The most common organizational problems are: lack } \\
\text { of transparency, trust, cooperation, communication, } \\
\text { public participation and stakeholder involvement. } \\
\text { The most cited contractual issues are: risk allocation } \\
\text { and sharing, political support, credibility, easy } \\
\text { targeting, measurability of goals, and flexibility. }\end{array}$ \\
\hline $\begin{array}{l}\text { Review of studies } \\
\text { on the public - } \\
\text { private } \\
\text { partnerships } \\
\text { (PPP) } \\
\text { for infrastructure } \\
\text { projects }\end{array}$ & $\begin{array}{l}\text { CUI et } \\
\text { al. }(2018)\end{array}$ & $\begin{array}{l}\text { International } \\
\text { Journal of } \\
\text { Project } \\
\text { Management }\end{array}$ & $\begin{array}{l}\text { Systematic literature review (between } 1990 \text { and } \\
\text { 2017) systematized six main topics: Initial studies and } \\
\text { application of PPP (G1), economic viability and VFM } \\
\text { (G2), risk management and success factors (G3), } \\
\text { Drafting and contract management (G4), Performance } \\
\text { management (G5) and governance and regulation } \\
\text { (G6). Group 6 highlighted the importance of } \\
\text { improving PPP project governance and policies. }\end{array}$ \\
\hline $\begin{array}{l}\text { Increasing the } \\
\text { Governance } \\
\text { Standards of } \\
\text { Public-Private } \\
\text { Partnerships in } \\
\text { Healthcare. Evide } \\
\text { nce from Italy }\end{array}$ & $\begin{array}{l}\text { TORCHIA } \\
\& \\
\text { CALABRO } \\
(2018)\end{array}$ & $\begin{array}{l}\text { Public } \\
\text { Organization } \\
\text { Review }\end{array}$ & 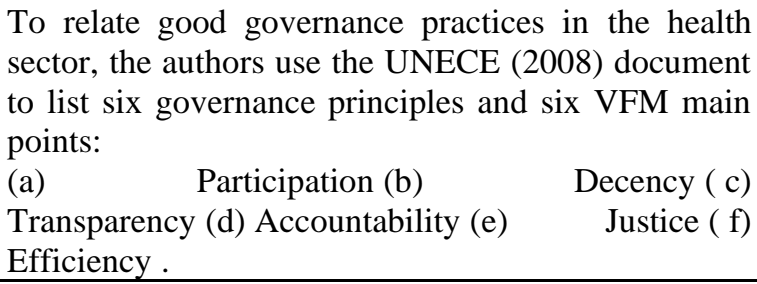 \\
\hline $\begin{array}{l}\text { The Core Roles of } \\
\text { Transparency and } \\
\text { Accountability } \\
\text { in the Governance } \\
\text { of Global Health } \\
\text { Public - Private } \\
\text { Partnerships }\end{array}$ & $\begin{array}{l}\text { REICH } \\
(2018)\end{array}$ & $\begin{array}{l}\text { Health } \\
\text { Systems } \\
\text { Reform }\end{array}$ & $\begin{array}{l}\text { The article presents a model for evaluating the } \\
\text { governance of public-private health partnerships, } \\
\text { using concepts of transparency } \\
\text { and accountability. From these two variables are } \\
\text { related inputs that include the contributions of each } \\
\text { partner. Processes include ways to make decisions } \\
\text { (including plans and budgets) and related } \\
\text { documentation and operational and strategic } \\
\text { decisions. Outputs include data that measures the } \\
\text { performance of the organization, the number of } \\
\text { beneficiaries, services provided, or medications } \\
\text { received. }\end{array}$ \\
\hline
\end{tabular}

Source: Elaborated by the authors.

The studies cited in Table 1 emphasize the need for governance in PPP contracts and have suggested a set of mechanisms to control opportunism and lower transaction costs. However, it is clear that there is still a gap on how in practice, 
this contractual incompleteness PPPs can cause harm to the public interest (RUFIN \& RIVERA-SANTOS, 2012; XIONG et al., 2018).

\section{Presentation of the integrative review to categorize governance mechanisms in PPPS}

\subsection{Governance and public interest defense mechanisms in PPPs}

Public-private partnerships can be understood as forms of hybrid organizations and as such represent particular challenges for public sector governance and accountability as they do not fully complement conventional forms of accountability, transparency and public accounting, thus, generating the need to produce more appropriate performance and evaluation reports (OPARA \& ROUSE, 2018). The nature and functioning of these hybrid arrangements consequently represents a transformation of the role of the state and its relationship with citizens that must be controlled so as not to detract from the purpose of the public interest to the detriment of private profit (OPARA \& RouSE, 2018).

The governance of PPPs can be seen then as the coordination of activities aimed at driving and managing PPPs, establishing organizational structures, performing decision-making procedures, and using instruments such as contracts and agreements (HURK \& VERHOEST, 2016). PPP assessment and governance metrics should consider technical issues, such as improving the quality of services, matching knowledge and experience with partners, contractual considerations that allow for the intermediation of inter-state interests, and responsiveness and legitimacy between partners (with clear responsibilities assigned) (BRINKERHOFF \& BRINKERHOFF, 2011). Aspects of good governance of partnership can be summarized in principles, which guide its operation and explicit goal.

In 2012, the OECD issued a document setting out specific governance principles for public-private partnerships. According to this document, the public governance structure for PPPs must be monitored at the highest political level, so that a whole government approach ensures accessibility, transparency and VfM. It also emphasized that the current financial crisis makes management transparent and prudent, as well as long-term governmental commitments in the case of partnerships. 
The recommendations cover three areas that can be listed in Figure 2: (1) establishing a predictable and legitimate institutional framework supported by competent authorities with sound human and financial resources; (2) support the selection of PPPs in VfM; and (3) use the budget process transparently, minimizing fiscal risks and ensuring the proxy process integrity (OECD, 2012).

Figure 2 - Summary of the Principles of Governance Related to PPPs

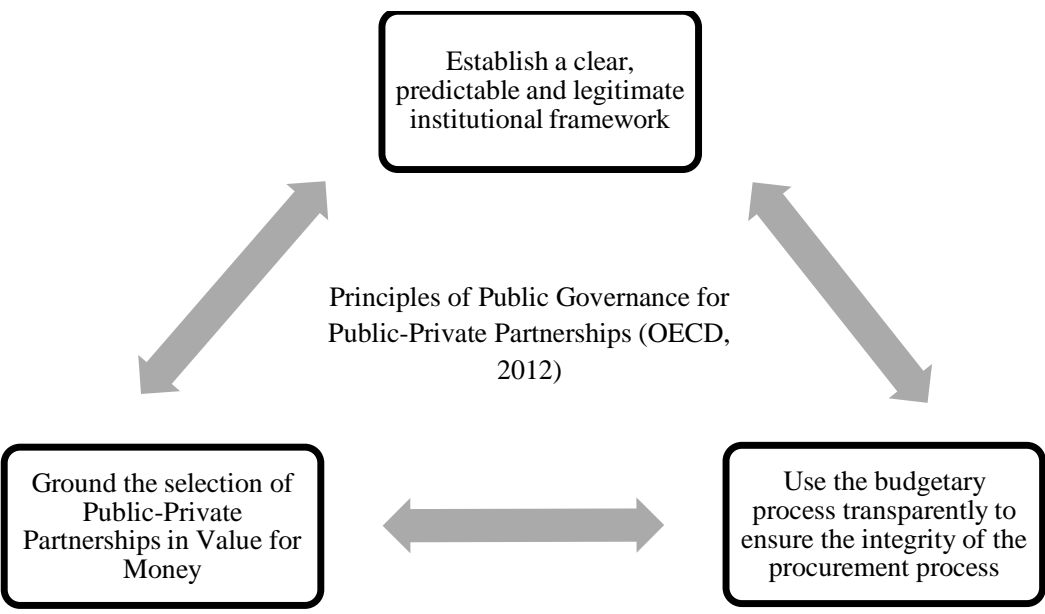

Source: Elaborated by the authors based on OECD (2012).

In addition to these principles proposed by the OECD (2012), the document titled Introduction to People-First Public Private Partnerships in Support of the United Nations (UNITED NATIONS, 2019) reinforces ten principles to guarantee PPPs which are traditionally designed for the purpose of VfM (facing a financial approach and costs), have focused on the Value for People, facing an increase in quality and user satisfaction. This project began in 2015 as the United Nations adopted the "Sustainable Development Goals " as part of the 2030 Agenda, encouraging and identifying PPP models that place the public interest first, adopting a new terminology called PPP "People-first".

Models of PPP that add "value to the people" are defined as those who minimize and share the risks in an equative manner, improve the results and are aligned with sustainable financing and equitable projects (UNITED NATIONS, 2019). In this scope, a PPP project people-first can be defined as one that promotes access to essential public services for all, with the results of sustainable development as a goal (UNITED NATIONS, 2019). 
These principles (OECD, 2012; UnITED NATIONS, 2019) are believed to be in line with TCT's assumptions regarding the three attributes of a governance structure: incentive intensity; administrative control and legal rule regime (WILLIAMSON, 1999). These principles established by the OECD (2012) and TCT's governance attributes intended to establish the necessary conditions for the design of governance mechanisms capable of overcoming the possible institutional deficiencies, unbalanced risk and finance distributions that may unbalance the public interest in contracts. Figure 3 demonstrates the theoretical logic that guided the selection in the literature of the governance mechanisms described below.

Figure 3 - Relationship Between Theoretical Attributes, Principles and Governance Mechanisms

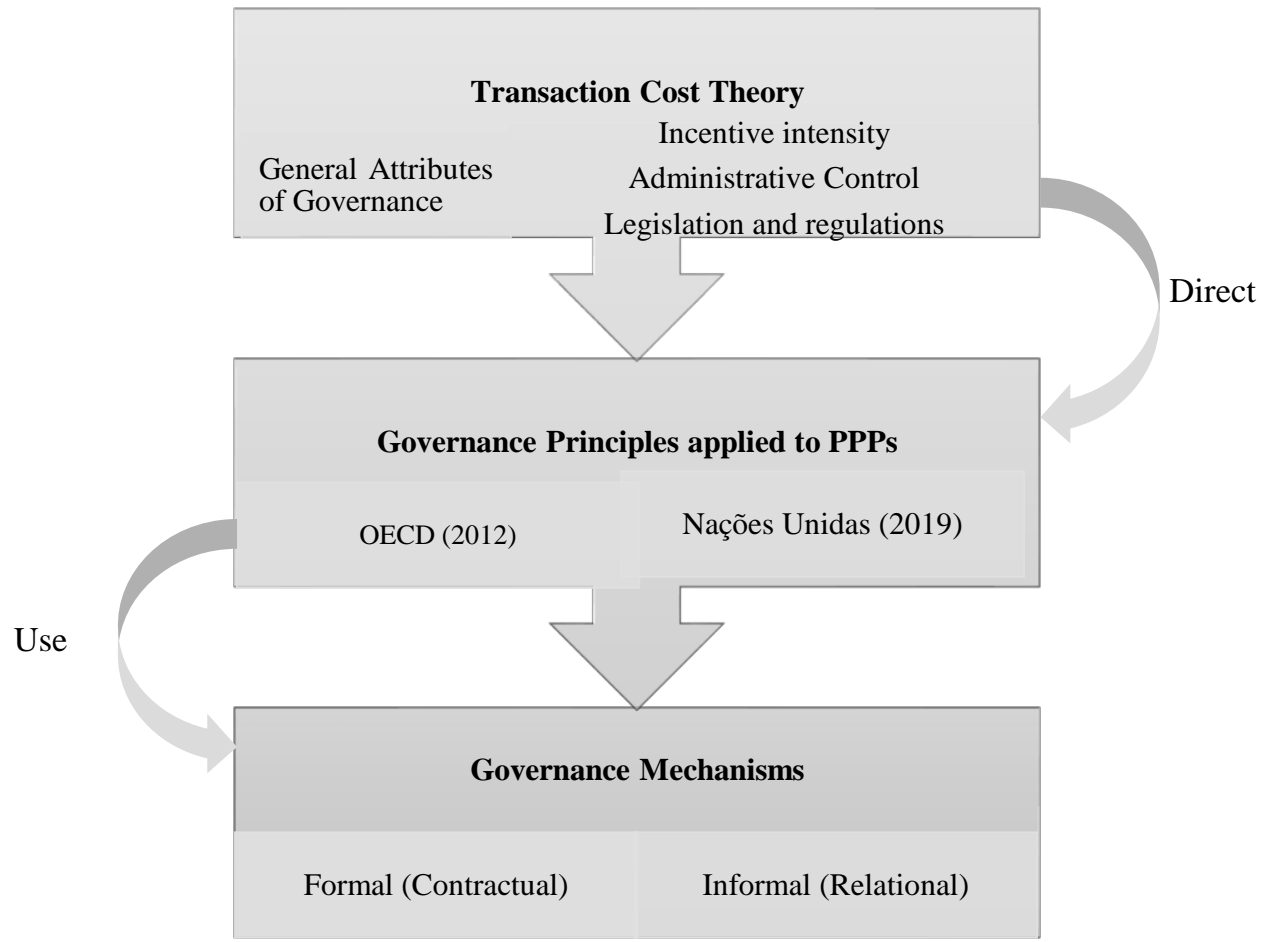

Source: Elaborated by the authors.

Based on theoretical logic exposed on Figure 3, the second step of this integrative review organized the governance mechanisms according to three principles proposed by the OECD (2012). Table 2 is a theoretical mapping of the principles of governance of PPPs, which associates governance mechanisms that focus both on the financial performance and in the satisfaction of stakeholders (following the guidance of the principles established by the United Nations (2019)). 
Table 2 - Prior Definition of Governance Mechanisms Grouped by Principles

\begin{tabular}{|c|c|c|}
\hline \multicolumn{3}{|c|}{ Governance Principles } \\
\hline $\begin{array}{c}\text { Clear and Legitimate } \\
\text { Institutional Framework }\end{array}$ & Project rationale in VfM & Transparent and Just Budget Process \\
\hline $\begin{array}{l}\text { Rules and Legislative } \\
\text { Aspects [3]; [7]; [8]; [10] } \\
\text { Contractual Provisions [4] } \\
\text { [9] } \\
\text { Organizational } \\
\text { Factors [1]; [2]; [4]; [6]; [8]; [10 } \\
\text { ] }\end{array}$ & $\begin{array}{l}\text { Risk } \\
\text { Sharing [5]; [6]; [7]; [9]; [10 } \\
\text { ] } \\
\text { Pre-contractual aspects } \\
\text { [6]; [8]; [10] } \\
\text { Competitive Economic } \\
\text { Environment } \\
\text { Guarantee [6]; [8] }\end{array}$ & $\begin{array}{l}\text { Transparency } \\
\text { and Accountability [1]; [2]; [3]; [4]; [6]; [8]; [10] } \\
\text { Internal control and monitoring [5]; [7] } \\
\text { Budget and fiscal accessibility [3]; [4]; [7]; [8] } \\
\text { Stakeholder participation [1]; [2]; [4]; [5]; [6]; [1 } \\
0\end{array}$ \\
\hline $\begin{array}{l}\text { [1] BOVAIRD (2004); [2] } \\
\text { (2014); [6] XIONG } \text { et. } \\
\text { (2018); [8] FIRMINO (201 }\end{array}$ & $\begin{array}{l}\text { NECE (2008); [3] OECD } \\
a l \quad(2018) ; \\
\text { [9] UNITED NATIONS }\end{array}$ & $\begin{array}{l}\text { 2012); [4] WORLD BANK (2013); [5] IFAC } \\
\text { 7] CUI } \\
\text { 019); [10] WORLD BANK (2019). }\end{array}$ \\
\hline
\end{tabular}

Source: Elaborated by the authors.

The following subsections will detail each of these mechanisms, justifying from the literature on TCT how they can help PPPs align their objectives with the proposed principles of securing public interest in contracts. As proposed, this article intends to contribute to the construction of a systematic vision of governance in public-private partnerships, based on the categorization of the main principles and mechanisms for the defense of the public interest.

It has been found that the categorization of the mechanisms was interactively adjusted, during the examination of the selected works, to arrive at the final systematization of a set of principles pointed out in the literature. Thus, the survey led to the identification of the following governance principles applied to PPPs and their respective governance mechanisms: Clear and Legitimate Institutional Framework; Guaranteed VfM; and Transparent and Just Budget Process, which will be described below.

\subsubsection{Clear and Legitimate Institutional Framework}

Based on the reviewed literature, it is clear that there is a need to organize and reassess the establishment of strong legal and regulatory frameworks that can clarify the legal authority. Additionally, the state must grant concessions without weakening its concern for users and the quality of service provided, ensuring a fair and efficient procurement process that makes the project financially viable and provides margins for 
negotiations and possible tariff balances that do not harm the public sector (OPARA \& RouSE, 2018).

Regarding the governance principle of the legal framework cited by the OECD (2012), Torchia, Calabro and Morner (2015) corroborate by emphasizing the creation of a transparent and solid regulatory framework as a necessary precursor for the good performance of partnerships. It can also be said that this principle reinforces necessary authority for public sector to oversee and monitor public sector, both in the public interest and in the interests of private actors.

Contract-based governance arrangements focus on developing legal and formal agreements that specify the rights and obligations of organizations involved in a partnership (ALONSO \& ANDREWS, 2018). The main advantage of contract based on solid governance mechanisms is that they reduce transaction costs associated with coordinating and managing various activities performed by different partners, aligning objectives. Explicit targets provide clarity of goals required for the pursuit of objectives, helping partners resolve conflicts as they arise (ALONSO \& ANDREWS, 2018).

On the necessary contractual arrangements in a PPP context, Benitez- Ávila et al. (2018) state that these relate to risk transfer and payments that are benchmarks for the development of rules (relational norms) that allow managers to interact with each other and deal with potential issues and conflicts. Behind these relational norms, values such as communication, inclusion and open discussion are emphasized using the PPP contract as a reference. For the authors, this is a key element in aligning the accountability and transparency requirements of public administration with profits of private organizations (BENITEZ- ÁVILA et al., 2018). This social aspect between partners that involves operation of efficient relational standards, allows partners to mobilize resources and coordinate activities, building and strengthening trust. This aspect was noted by Firmino (2018), who argues that specific PPP legislation should establish business guidelines and principles that ensure competitiveness and legal and economic protection to safeguard the private partner.

Organizational issues concern the structure, behavior and culture of contracting parties in PPPs that can reduce conflicts between them. These issues are responsible for maintaining trust, cooperation and communication between the actors in the partnership (XIONG et al., 2018). These factors are linked to public sector capacity with respect to the ability of innovation and learning in the processes that relate to partnerships. Cooperation, 
which is considered a key feature in the PPP concept, suggests sharing common goals and actions among participants of partnerships. In relation to TCT, such features encourage situations mutually beneficial and prevents the dominance of a partner or opportunistic behavior (XIONG et al., 2018).

Table 3 - Summary of the Conditions for a Clear and Legitimate Institutional Framework and its Variables Found in the Literature

\begin{tabular}{|c|c|c|}
\hline Category & Meaning & Characteristics \\
\hline $\begin{array}{l}\text { Contractual Provisions } \\
\text { (WORLD } \\
\text { BANK (2013); WORLD } \\
\text { BANK (2019) } \\
\text { BENÍTEZ- ÁVILA et } \\
\text { al. (2018) }\end{array}$ & $\begin{array}{l}\text { Contractual governance is } \\
\text { considered as a formal } \\
\text { mechanism consisting of } \\
\text { rules defined in } \\
\text { documents. Aims to } \\
\text { minimize the risks and } \\
\text { possible additional } \\
\text { transaction costs, } \\
\text { establishing standards and } \\
\text { aligning the different } \\
\text { objectives to the mission of } \\
\text { the partnership. }\end{array}$ & $\begin{array}{l}\text { - The contract is simple to understand; } \\
\text { - The contract has many possibilities to } \\
\text { impose sanctions if its terms are not met; } \\
\text { - The contract is characterized by target } \\
\text { values and fixed standards, regardless of the } \\
\text { circumstances; } \\
\text { - The contract provides space for negotiation } \\
\text { and relaxation of clauses; } \\
\text { - Financial risk is explicitly shared between } \\
\text { public and private partners; } \\
\text { - There are organizational arrangements to } \\
\text { facilitate interaction between the parties. }\end{array}$ \\
\hline $\begin{array}{l}\text { Rules and Legislative } \\
\text { Aspects (OECD, } \\
\text { 2012); CUI et al. (2018); } \\
\text { FIRMINO (2018); } \\
\text { UNITED NATIONS } \\
(2019)\end{array}$ & $\begin{array}{l}\text { It establishes laws and rules } \\
\text { that define the main } \\
\text { institutional roles and } \\
\text { responsibilities in relation } \\
\text { to PPPs. This requires that } \\
\text { authorities (responsible for } \\
\text { the bidding, auditing, } \\
\text { enforcement and } \\
\text { enforcement of PPPs) and } \\
\text { industry regulators } \\
\text { receive clear sufficient } \\
\text { instructions and } \\
\text { resources to ensure a } \\
\text { prudent process (OECD, } \\
\text { 2012). } \\
\text { Bureaucracy must be } \\
\text { minimized and new and } \\
\text { existing regulations must be } \\
\text { carefully (UNITED } \\
\text { evaluated (UNI) } \\
\text { NATIONS, 2019). }\end{array}$ & $\begin{array}{l}\text { - There is a general framework law for PPPs; } \\
\text { - There is a breakdown by sector of specific } \\
\text { activity and public procurement; } \\
\text { - Definition of contractual terms on: payment } \\
\text { and benefit sharing mechanisms; adequate } \\
\text { risk distribution matrix; } \\
\text { - There are } \\
\text { on guarantees offered to the partners; } \\
\text { - Definition of minimum performance } \\
\text { indicators for each PPP sector; } \\
\text { - Conditions of negotiation, exit and } \\
\text { termination of the contract; } \\
\text { - Standardization of tender procedures and } \\
\text { contracts. }\end{array}$ \\
\hline $\begin{array}{l}\text { Organizational Factors } \\
\text { (BOVAIRD, } \\
\text { UNECE, } \\
\text { 2008; WORLD } \\
\text { 2013; } \\
\text { 2001; XIONG et } \quad \text { IFAC, } \\
\text { 2018; } \\
\text { NATIONS, 2019) }\end{array}$ & $\begin{array}{l}\text { The organizational factors } \\
\text { needed for public } \\
\text { governance in PPPs are } \\
\text { those that allow for a more } \\
\text { harmonious relationship } \\
\text { between two sectors, which } \\
\text { depends on the clear } \\
\text { assignment } \\
\text { tasks; conflict resolution } \\
\text { and public sector } \\
\text { innovation capacity and } \\
\text { efficiency. These factors }\end{array}$ & $\begin{array}{l}\text { - Degree of qualification of personnel } \\
\text { involved / number of experts nominated to } \\
\text { evaluate the project; } \\
\text { - Training and learning system employed in } \\
\text { PPP analysis; } \\
\text { - Degree of innovation for strategic } \\
\text { planning and process design; } \\
\text { - Reliability of the public sector in its } \\
\text { financial capacity; } \\
\text { - Degree of innovation bidding procedures } \\
\text { and new acquisitions; } \\
\text { - Degree of innovation for project financing; }\end{array}$ \\
\hline
\end{tabular}




\begin{tabular}{|c|c|c|}
\hline Category & Meaning & Characteristics \\
\hline & $\begin{array}{l}\text { are reflected in the joint } \\
\text { capacity of the partnership } \\
\text { and its success. }\end{array}$ & $\begin{array}{l}\text { - Effective contract management; } \\
\text { - Effective management of operation cost, } \\
\text { time and quality; } \\
\text { - Efficient use of materials / resources; } \\
\text { - Effective management of prominent } \\
\text { techniques and skills; } \\
\text { - Effective conflict management; } \\
\text { - Effective facility management. }\end{array}$ \\
\hline
\end{tabular}

Source: Elaborated by the authors.

\subsubsection{Guaranteed Value for Money Principle}

Regarding the second principle of governance applied to PPPs, the literature shows that the main point for a government to opt for a PPP delivery model is to increase VfM, so a PPP project should only be considered when generating a positive net gain greater than a common public sector hiring projects. The VfM is reached when a PPP project is able to generate: (a) cost efficiencies through construction, operating and/or maintenance costs; (b) time savings through early project completion; (c) quality improvements through enhanced service delivery (GRIMSEY \& LEWIS, 2005).

A comprehensive evaluation of the VfM Project lifecycle includes qualitative and quantitative considerations in all contractual steps, which may involve construction, financing, maintenance and management of the assets underlying the PPPs. Such considerations include full cost, physical quality, quality and scope of service, asset conditions (eg. maintenance and sustainability), and social or economic impacts on the local community and the public (LIU et al., 2018).

The cost of a PPP is compared to an equivalent and usually hypothetical project that is assumed to be publicly funded and managed according to a traditional approach, which is often Public Sector Comparator (CSP) (O'NOLAN \& REEVES, 2017). In general, the VfM analysis is a mandatory part of the PPP process in some countries as a way of demonstrating the cost/benefit. A comparator of the public sector compares the proposals of the PPP with the most efficient form of delivery for a project reference of the public sector in the traditional procurement model (JOHNSTON \& GUDERGAN, 2007). This comparison serves as a basis to substantiate the merits of PPPs and to prevent political symbolism, where the partnership can be interpreted as a purely commercial enterprise with economic interests with the possibility of a political interest that is likely to undermine integrity and trust in the public sector, provoking unethical, intriguing and political motivations (JOHNSTON \& GUDERGAN, 2007). 
As part of the comparison with the public sector, the most appropriate type of governance arrangement needs to identify appropriate risk implications. PPP models then require a robust governance system that engages all stakeholders to address intangible risks and uncertainties that are not anticipated in the contract (ALONSO et al., 2016). Appropriate risk allocation when considering three elements: 1) the type of risk to be allocated, 2) which party should accept and bear the risk 3) when to allocate the risk, and what applications of appropriate strategies to prevent or minimize its consequences (ALONSO et al., 2016). The resulting inability to control risk will be reflected in a project governance failure, thus resulting in an unsuccessful project and damage to the public interest.

In the context of public procurement, transaction costs include costs of consultancy, research, trading and others incurred by the public sector when you choose to develop a long-term contractual relationship with third parties (O'NOLAN \& REEVES, 2017). In terms of TCT, the extent of transaction costs is determined by the transaction characteristics (WILLIAMSON, 1985) and in the case of PPPs, it also depends on a competitive, fair and transparent bidding able to attract serious bidders with sufficient skills in financial and commitment terms that can carry out the project from start to finish, honoring the contractual agreement (UNITED NATIONS, 2019). Based on this premise, competition is essential for other governance issues because in a competitive economic environment, the private sector may disclose more cost information, increasing the likelihood of more qualified bidders (XIONG et al., 2018).

While a stable and competitive economic environment stimulates competition and reduces transaction costs, explicit specification of criteria and procedures needed to execute a PPP project is required. This preliminary analysis of the projects enables the necessary cash flows to be adjusted over the period and is the most important phase of planning in a partnership (UNited NATIONS, 2019). Table 4 summarizes the VfM into three categories consisting of a) Preliminary project analysis that highlights the merits justifying the viability of a PPP project; b) Analysis of the competitive economic environment in which the proposal was made; and c) Risk assessment and sharing, which is a key factor in the elaboration of a PPP. 
Table 4 - Summary of Mechanisms for a Proper Vfm Assessment and its Variables Found in the Literature

\begin{tabular}{|c|c|}
\hline Category & Meaning \\
\hline $\begin{array}{l}\text { Analysis of the } \\
\text { preliminary phase of } \\
\text { the project (LIU et } \\
\text { al., 2018; LIU et } \\
\text { al., 2015) }\end{array}$ & $\begin{array}{l}\text { Preliminary phase analysis is the } \\
\text { process that ensures transparent and } \\
\text { competitive planning and contracting } \\
\text { and is vital to the success of PPPs, } \\
\text { because if mistakes are detected in the } \\
\text { references required in the bidding, it } \\
\text { could lead to inadequate partner } \\
\text { selection and loss of service } \\
\text { efficiency (LIU et al, 2018). } \\
\text { LIU et al. (2016) argue that the } \\
\text { planning phase requires a pre-project } \\
\text { study (investment analysis and } \\
\text { production specification); feasibility } \\
\text { study (political, economic, social, and } \\
\text { financial analysis of accessibility and } \\
\text { liquidity) and a forecast of risks and } \\
\text { their treatment (risk identification, } \\
\text { assessment, allocation, mitigation, } \\
\text { monitoring and periodic review). }\end{array}$ \\
\hline
\end{tabular}

\begin{tabular}{|c|c|}
\hline $\begin{array}{lr}\text { Participation } & \text { and } \\
\text { involvement } & \text { of } \\
\text { stakeholders } & \\
\text { (GRILO, } & 2008 ; \\
\text { TORCHIA } & \& \\
\text { CALABRO, 2018) }\end{array}$ & $\begin{array}{l}\text { Stakeholder satisfaction is the } \\
\text { guarantee that the democratic guiding } \\
\text { principles of PPPs are based on the } \\
\text { benefit to society, and especially on } \\
\text { the concept of equity in public } \\
\text { services. Implementation of a PPP } \\
\text { requires critical political reflection, } \\
\text { especially when interactions between } \\
\text { the public and private sectors are } \\
\text { susceptible to political manipulations } \\
\text { that may compromise welfare. }\end{array}$ \\
\hline
\end{tabular}

- There is analysis and specification of the macro environmental coverage (political, economic, social and legal) of the project;

- There was transparency and competitiveness of the bidding process;

- The company selection process complies with the legal and regulatory framework;

- There was adequate negotiation of the definition of service and necessary resource outflows;

- There was definition of desired quality elements and materials management;

- There are specifications on the ratio of payments and the desired effectiveness and efficiency;

- There are specifications on the occupational health and safety of those involved;

- There was feasibility study/business case study (finance, technical and engineering)

- The project duration is justified and based on expected results.

- Stakeholders were identified and consulted, including potentially adversely affected parties, such as communities surrounding the project and staff to be transferred to the private sector;

- Process compliance analysis with applicable law, the consortium suitability to contract with the government;

- Compliance with requirements for licensing public service quality standards;

- The contract includes clauses regarding the involvement of external stakeholders (citizens, environmental groups, other public actors) and their opinions;

- Is there any form of public consultation or hearing in the project decision making process;

- Participation and supervision of municipal councils in the performance of partnerships. 


\begin{tabular}{|c|c|c|}
\hline Category & Meaning & Characteristics \\
\hline $\begin{array}{l}\text { Risk Sharing } \\
\text { (KEERS } \\
\text { \& FENEMA, } \\
\text { 2018; GRIMSEY \& } \\
\text { LEWIS, 2002; } \\
\text { BURKE } \\
\text { \& DEMIRAG, } \\
\text { 2017) }\end{array}$ & $\begin{array}{l}\text { Appropriate identification and } \\
\text { allocation of risks, considering the } \\
\text { following factors: } \\
\text { Organizational factor (size, business } \\
\text { and information, structure, } \\
\text { management support, safety culture, } \\
\text { policy, legislation); } \\
\text { Human factor (management } \\
\text { knowledge, } \\
\text { communication skills, judgmental } \\
\text { competence, eg risk awareness); } \\
\text { Technical factor (system and network } \\
\text { complexity, compatibility, } \\
\text { vulnerability) (KEERS \& FENEMA, } \\
\text { 2018.) }\end{array}$ & $\begin{array}{l}\text { - Estimation of technical risk; } \\
\text { - Estimation of Operating risk; } \\
\text { - Estimation of demand risk } \\
\text { and insufficient funding (ie, lower than } \\
\text { expected to complete tasks); } \\
\text { - Estimation of financial } \\
\text { risco. Involves errors in project } \\
\text { estimation, revenue streams, and project } \\
\text { financing costs; } \\
\text { - Estimation of regulatory } \\
\text { risk/political; } \\
\text { - Estimation of environmental risk. }\end{array}$ \\
\hline
\end{tabular}

Source: Elaborated by the authors.

These mechanisms

necessary

to

ensure VfM focuses

on

directing performance measurement to stakeholder vision as well as an ability to accommodate demographic and environmental (ie political, economic, social and legal) changes (LIU et al., 2018). The VfM assessment needs to focus more on the public interest, which includes: (1) a comprehensive assessment that considers benefits as well as macro impacts on local communities and the public (eg social benefits and economic development); and (2) effective and efficient organizational learning to absorb emerging 'lessons' from projects. (LIU et al., 2018).

Taking into account the wishes of stakeholders (citizens, non-governmental organizations, employees/unions, civil society, media, etc.) in PPPs is one of the most important factors in ensuring democratic principles (OPARA \& ROUSE, 2018). PPPs incorporate complex legal and accounting structures that lead to different obligations and benefits, and thus alternative governance models. Much of the current literature on PPP governance is concerned with how to define "good governance structures" and the benefits that PPP structures can bring. Despite this concern, there is empirical recognition that good governance has not been the top priority of governments when adopting PPPs, but rather budgetary and financing factors (OPARA \& ROUSE, 2018). The purpose of user/citizen satisfaction should be transferred to the contractual and transparent objectives of the partnership. 


\subsubsection{Principle of Transparent and Healthy Budgetary Process}

The Transaction Cost Theory reinforces that clear and transparent goals are the key to achieving the commitment in interorganizational relationships (WILLIAMSON, 1979). Performance goals are also part of those goals because they can reduce coordination costs and increase value creation benefits (ALONSO \& ANDREWS, 2018). The budget factor on PPPs gets a lot of attention when thinking about good governance structures. This attention is aggravated to when there is pressure on governments to reduce their debts. This pressure can create incentives to outsource service infrastructure provision and management rather than conventional procurement, disregarding VfM analysis and inhibiting the proactive governance needed to engage all parties involved in the partnership to safeguard rather than predict the VfM (SANTANDREA et al., 2015).

The literature on transparency in PPP recognizes that transparency or not in this hybrid structure has to do with the extent to which the entity's public and private shows to interested parties relevant information about their own decision-making processes, procedures, operation, and performance (REYNAERS \& GRIMMELIKHUIJSEN, 2015). For these authors, a crucial component in defining transparency is the availability of information, which not only means that information is visible and accessible, but can be understood and inferred from as well.

The main benefits of transparency when it comes to PPPs are related to the possibility of social control, accountability and monitoring of resources and shared responsibilities (WORLD BANK, 2013). Together, these benefits offer democratic assurances that the service is being delivered to the best of its ability, and that the responsibility delegated to the private partner is honoring its commitments. The need for transparency increases when considering possible opportunistic behavior between contractual parties and information asymmetry (between government and private partner, and between government and society).

Another important point is that "PPPs address important issues of democratic governance due to the changed nature of the state when it is engaged in cooperative activities with private actors" (SKELCHER, 2010, p. 265). Consequently, a democratic deficit caused by a deficit in accountability mechanisms must be avoided, as there is a growing difference in expectations between what is promised or expected and what can 
actually be delivered by politicians. This can be verified by analyzing whether or not it is in the public interest (SKELCHER, 2010). The public interest in a PPP is typically to maximize the social welfare of a good infrastructure or good public service that needs to be ensured through efficient accountability and a constant monitoring system.

In order to hold partners accountable for their actions, it is imperative to have clear governance monitoring and contractual mechanisms, and to clarify partners' rights and obligations. Clarity in these relationships is necessary to avoid ambiguity (WARSEN et al., 2018). The accountability and transparency process cited in Table 5 are needed to improve the efficiency and quality of service (REYNAERS \& RIMMELIKHUIJSEN, 2015). This need for transparency and accountability results in greater demand for a more robust assessment as a governance tool, which will be detailed in the following session.

Table 5 - Synthesis of the Mechanisms for a Transparent and Healthy Budget Process and its Variables Found in the Literature

\begin{tabular}{|c|c|c|}
\hline \multicolumn{3}{|c|}{ Transparent and Healthy Budget Process } \\
\hline Category & Meaning & Characteristics \\
\hline $\begin{array}{l}\text { Transparency an } \\
\text { d Accontability ( } \\
\text { REYNAERS \& } \\
\text { RIMMELIKHU } \\
\text { IJSEN, 2015; } \\
\text { WORLD } \\
\text { BANK, 2013) }\end{array}$ & $\begin{array}{l}\text { The information available about a } \\
\text { project is transparent when there is } \\
\text { "visibility" of the information, and if } \\
\text { this information makes it possible to } \\
\text { infer precise conclusions about the } \\
\text { project and its implications, } \\
\text { implying a better process of } \\
\text { accountability (BOATENG et al., } \\
\text { 2017). } \\
\text { In the case of complex relationships } \\
\text { involving the term to accountability } \\
\text { in this context as the issue is } \\
\text { conceptualized as an accountability } \\
\text { of public acts in society and } \\
\text { establishing penalties, basing itself } \\
\text { on justice, integrity, and do what is } \\
\text { right. }\end{array}$ & $\begin{array}{l}\text { - Contract Disclosure: There is public } \\
\text { availability of the actual signed contract } \\
\text { and any substantial changes; } \\
\text { - Contract Summary: There is a } \\
\text { document presenting the project and the } \\
\text { contract in plain language, describing the } \\
\text { object and conditions, deadline, quality } \\
\text { and requirements and performance } \\
\text { indicators, reward/penalties scheme and } \\
\text { monitoring system; } \\
\text { - Government guarantees: Availability } \\
\text { of warranty information, including in the } \\
\text { form of letters, etc.; } \\
\text { - Disclosure of Performance Reporting } \\
\text { and Auditing: Information on disclosure } \\
\text { of performance reports for PPP } \\
\text { Operators, Contract Managers, Third } \\
\text { Party Reviews and audit reports. }\end{array}$ \\
\hline $\begin{array}{l}\text { Affordability } \\
\text { (accessibility) } \\
\text { (OECD, 2012) }\end{array}$ & $\begin{array}{l}\text { PPPs (because of their long-term } \\
\text { characteristics) are more difficult to } \\
\text { integrate into the annual budget } \\
\text { process because they have variable } \\
\text { expenses that can be modified } \\
\text { throughout the contract. A sound } \\
\text { and legitimate budget process is one } \\
\text { that is accessible (financial, legal } \\
\text { and social) and follows the legal } \\
\text { requirements (budgeting, } \\
\text { projections and contingencies), } \\
\text { allowing the PPP project to be } \\
\text { accessible and sustainable over the } \\
\text { years. while maintaining a balance }\end{array}$ & $\begin{array}{l}\text { - The estimated values in the partnership } \\
\text { project respect the Fiscal Responsibility } \\
\text { Limits; } \\
\text { - Budgetary documentation shall } \\
\text { disclose all contingent costs and } \\
\text { liabilities; } \\
\text { - The government must protect itself } \\
\text { against waste and corruption by ensuring } \\
\text { the integrity of the procurement } \\
\text { process. The necessary acquisition skills } \\
\text { and powers should be made available to } \\
\text { the relevant authorities; } \\
\text { - The project has Future Budget } \\
\text { flexibility; }\end{array}$ \\
\hline
\end{tabular}




\begin{tabular}{|c|c|c|}
\hline \multicolumn{3}{|c|}{ Transparent and Healthy Budget Process } \\
\hline Category & Meaning & Characteristics \\
\hline & $\begin{array}{l}\text { between government revenue and } \\
\text { expenditure. }\end{array}$ & $\begin{array}{l}\text { - The government budgeting and } \\
\text { accounting system should provide a clear, } \\
\text { transparent and true record of all PPP } \\
\text { activities. }\end{array}$ \\
\hline $\begin{array}{l}\text { Monitoring Systems } \\
\text { (Grilo, 2008) }\end{array}$ & $\begin{array}{l}\text { A monitoring system comprises the } \\
\text { tools and attributes needed to } \\
\text { minimize informational asymmetry } \\
\text { between the parties throughout the } \\
\text { contract, enabling greater alignment } \\
\text { of interests between partners, } \\
\text { preventing acts of corruption and } \\
\text { misuse of purpose during the } \\
\text { project. }\end{array}$ & $\begin{array}{l}\text { - The processes and procedures for } \\
\text { identifying the quality of investment in } \\
\text { the PPP project are defined; } \\
\text { - There is a focus on performance } \\
\text { analysis during the operational phase and } \\
\text { organizational learning through the } \\
\text { definition of PPP contract management } \\
\text { processes and procedures; } \\
\text { - There are identification of forms of } \\
\text { evaluation and performance indicators } \\
\text { for each area of performance of the } \\
\text { contract; } \\
\text { - There is periodic evaluation of the } \\
\text { goals and indicators established in the } \\
\text { contract; } \\
\text { - Payments are subject to verification of } \\
\text { the quality of service provided; } \\
\text { - The partnership goes through ongoing } \\
\text { quality reviews and auditing by the } \\
\text { government. }\end{array}$ \\
\hline
\end{tabular}

Source: Elaborated by the authors.

Importantly, while the variables listed in Table 5 attempt to optimize governance aspects over the budget aspect of PPPs, contract incompleteness is inevitable, considering that long-term contracts will necessarily face technological innovations, demographic, managerial and political changes. Concerning these uncertainties, Hurk and Verhoest (2016) argue that the long-term factor of partnerships (which in Brazil ranges from 5 to 35 years) requires flexibility, trust and management ability to a greater degree in partnerships than in ordinary contracting. For this reason, the factors listed need to try to ensure that actors are held accountable for providing efficient, effective and equitable services.

\section{Final remarks}

Inserted in the theme of public sector reforms that brought new forms of hybrid organizations to provide public services, this research aimed to identify the characteristics and conditions used to implement governance mechanisms that ensure the public interest in existing PPP contracts. Therefore, an integrative literature review of the main national and international journals on the subject was 
conducted. Thus, the present review grouped the governance mechanisms used to ensure public interest with existing PPP contracts.

Verification on how to organize governance interface between public actors and private parties in the PPP project and its foundations challenges the role of contractual governance and other mechanisms in the value creation process for partnerships. Based on previous research on the subject of public governance, this study lists - based on the three principles established by the OECD (2012) (Clear and Legitimate Institutional Framework; Rationale in the proper VfM assessment and Transparent and Healthy Budgetary Process) - public governance mechanisms with its contractual, monitoring, accountability and organizational factors as core characteristics, highlighting their respective theoretical potentials to contribute directly to the defense of the public interest and to the performance of partnerships.

International literature also points out that failures of PPPs is related to the lack of an effective VfM assessment that considers the risks and nonfinancial factors surrounding the project (LIU et al., 2015). To address this need, the research approach of Liu et al. (2015, 2016, 2018) was incorporated in this review, seeking a form of assessment that considers the various life cycles and their expected performances, providing guidance and assistance in developing relevant and comprehensive processes.

The analysis of the international literature is extensive by pointing out that there are different success factors needed to defend partnerships as to the opportunism and different transaction costs involved. In particular, the research could muster and integrate from a theoretical point of view concepts from the Theory of Transaction Costs to list governance mechanisms, identified as necessary to ensure the public interest in all project phases. Such mechanisms and requirements can then be used as indicators, strengthening its relevance in the practical context, especially in Brazil, where the literature is scarce.

As a limitation, subjectivity is presented in the bibliographical selection of this research, which chose to outline and choose articles and manuals that emphasize governance under the contractual aspect. The result of the categories and features cited in this article is theoretically significant because they may be used and synthesized for measuring PPP both in the previous and after stage of the engagement, ensuring that the VfM is being achieved as an effective evaluation metric and efficient mechanisms of governance are being established for a PPP. The insights offered are 
important about the essential role of public interest consideration in partnerships through appropriate governance and evaluation mechanisms. The results offered raise new research challenges for Brazil, such as relating to what extent governance influences the project quality level and throughout its life cycles.

\section{References}

Alonso, J. M.; ClifTON, J.; \& DiaZ-Fuentes, D. (2016). Public private partnerships for hospitals: Does privatization affect employment? Journal of Strategic Contracting and Negotiation, Vol. 2, Num. $\quad 4, \quad$ pp. 313-325. Doi: https://doi.org/10.1177/2055563617710619.

ALONSO, J. M., \& ANDREWS, R. (2018). Governance by targets and the performance of Cross-Sector partnerships: Do partner diversity and partnership capabilities matter? Strategic Management Journal. Vol. 40, Num. 4, pp. 556579. Doi: https://doi.org/10.1002/smj.2959.

Benítez-Ávila, C.; Hartmann, A.; Dewulf, G.; \& HENSELER, J. (2018). Interplay of relational and contractual governance in publicprivate partnerships: The mediating role of relational norms, trust and partners contribution. International Journal of Project Management, Vol. 36, Num. 3, pp. 429-443. Doi: https://doi.org/10.1016/j.ijproman.2017.12.005.

BoAteng, C. A.; Stafford, A.; \& Stapleton, P. (2017). The role of structure in manipulating PPP accountability. Accounting, Auditing, Accountability Journal, Vol. 30, Num. 1, pp. 119-144. Doi: https://doi.org/10.1108/AAAJ-012014-1590.

BovaIRD, T. (2004). Public-Private Partnerships: From contested concepts to prevalent practice. International Review of Administrative Sciences, Vol. 70, Num. 2, pp. 199-215.

Doi: http://dx.doi.org/10.1177/0020852304044250.

BRINKERHOFF, D. W. \& BRINKERHOFF, J. M. (2011), Public-Private Partnerships: Perspectives on Purposes, Publicness, and good Governance. Public administration and development, Vol. 31, Num. 2, pp. 2-14, 2011. Doi: https://doi.org/10.1002/pad.584.

BURKE, R. \& DEMIRAG, I. (2017). Risk transfer and stakeholder relationships in Public Private
Partnerships. Accounting Forum, Vol. 41, Num. 2, pp. 28-43. Doi: http://dx.doi.org/10.1016/j.

CAPPEllaro, G. \& Ricci, A. (2017). PPPs in health and social services: a performance measurement perspective. Public Money, Management, Vol. 37, Num. 6, pp. 417-424.Doi: https://doi.org/10.1080/09540962.2017.1344022

CuI, C.; LiU, Y.; HoPe, A.; \& WANG, J. (2018). Review of studies on the public-private partnerships (PPP) for infrastructure projects. International Journal of Project Management, Vol. 36, Num. 5, pp. 773-794. Doi: https://doi.org/10.1016/j.ijproman.2018.03.004.

CUTRIM, S.; Tristão, J. A. M.; \& TRISTÃo, V. T. V. (2017). Aplicação do Método Delphi para identificação e avaliação dos fatores restritivos à realização de parcerias público-privadas. Revista Espacios, Vol. 38, Num. 22, pp. 29-43.

EUROPEAN INVESTMENT BANK. (2011). The guide to guidance: How to prepare, procure, and deliver PPP projects. Disponível em: <http://www.eib.org/epec/resources/guide-toguidance-en.pdf.> Acesso em 20 de janeiro de 2019.

FIRMINO, S. I. (2018). Fatores críticos de sucesso das Parcerias Público-Privadas: Aspectos político-institucionais. Estudo de caso das rodovias em Portugal. Revista De Administração Pública, Vol. 52, Num. 6, pp. 1270-1281. Doi: http://dx.doi.org/10.1590/0034-761220170228.

GRILO, L. M. (2008). Modelo de análise da qualidade do investimento para projetos de parceria público-privada (PPP). Doctoral dissertation, Universidade de São Paulo.

GRIMSEY, D. \& LEWIS, M. K. (2002). Evaluating the risks of public private partnerships for infrastructure projects. International Journal of Project Management, Vol. 20, Num. 2, pp. 107- 
118. Doi: https://doi.org/10.1016/s02637863(00)00040-5.

GRIMSEY, D. \& LEWIS, M. K. (2005). Are public private partnership value for money? Account Forum, Vol. 29, Num. 4, pp. 345-378. Doi: https://doi.org/10.1016/j.accfor.2005.01.001.

IFAC. (2014). International Federation of Accountants. International Framework: Good Governance in the Public Sector. Disponível em: <https://www.ifac.org/system/files/publications/ files/International-Framework-Good-

Governance-in-the-Public-Sector-IFAC-

CIPFA.pdf>. Acesso em 9 de novembro de 2020.

IFAC. (2001). International Federation of Accountants. Study 13 - Corporate governance in the public sector: a governing body perspective. Disponível em: <https://www.ifac.org/system/files/publications/ files/study-13-governance-in-th.pdf.> Acesso em 9 de novembro de 2020.

Hodge, G. A. \& Greve, C. (2017). On PublicPrivate Partnership performance: A contemporary review. Public Works Management, Policy, Vol. 22, Num. 1, pp. 55-78. Doi: http://10.1177/1087724X16657830.

Hodge, G. A. (2004). The risky business of Public-private Partnerships. Australian Journal of Public Administration, Vol. 63, Num, 4, pp. 37-49. Doi: https://doi.org/10.1111/j.14678500.2004.00400.x.

Hurk, M. V. \& Verhoest, K. (2016). The challenge of using standard contracts in publicprivate partnerships. Public Management Review, Vol. 18, Num. 2, pp. 278-299. Doi: https://doi.org/10.1080/14719037.2014.984623.

Johnston, J. \& Gudergan, S. P. (2007). Governance of public-private partnerships: Lessons learnt from an Australian case? International Review of Administrative Sciences, Vol. 73, Num. 4, pp. 569-582. Doi: https://doi.org/10.1177/0020852307083459.

KeERs, B. M. \& FEnEMA, P. C. (2018). Managing risks in public-private partnership formation projects. International Journal of Project Management, Vol. 36, Num. 6, pp. 861-875. Doi: https://doi.org/10.1016/j.ijproman.2018.05.001.

KLIJn, E. H. \& KopPENJAN, J. (2016). The impact of contract characteristics on the performance of public-private partnerships (PPPs). Public
Money, Management, Vol. 36, Num. 6, pp. 455$462 . \quad$ Doi: https://doi.org/10.1080/09540962.2016.1206756

LiU, J.; Love, P. E. D. J. S.; Michael, R.; \& MonTy, S. (2014). Public-Private Partnerships: a review of theory and practice of performance measurement. International Journal of Productivity and Performance Management, Vol.63, Num. 4, pp. 499-512. Doi: https://doi.org/10.1108/IJPPM-09-2013-0154.

LiU, J.; Love, P. E. D.; DAVIS, P. R.; SMITH, J.; \& REGAN, M. (2015). Conceptual framework for the performance measurement of Public-Private Partnerships. Journal of Infrastructure Systems, Vol. 21, Num. 1, pp. 401-423. https://doi.org/10.1061/(asce)is.1943555x.0000210.

LiU, J. P. E. D.; Love, J.; SMith, J.; \& Matthews, C. Sing. (2016). Praxis of performance measurement in Public-private Partnerships: Moving beyond the iron triangle. ASCE Journal of Management in Engineering, Vol. 32, Num. 4. Doi: https://doi.org/10.1061/(ASCE)ME.19435479.0000433,04016004.

LiU, J.; Love, P. E. D.; \& SMith, J. (2018). Evaluation of public-private partnerships: A lifecycle performance prism for ensuring value for money. Environment and Planning C: Politics and Space, Vol. 36, Num. 6, pp. 1133-1153. Doi: https://doi.org/10.1177/2399654417750879.

MAURYA, D. S., \& SRIVASTAVA, A. K. (2018). Managing partner opportunism in public-private partnerships: the dynamics of governance adaptation. Public Management Review, pp. 1-23. Doi: https://doi.org/10.1080/14719037.2018.1559341

OECD. (2012). Principles for public governance of Public-Private Partnerships. Disponível em: $<$ https://www.oecd.org/governance/budgeting/P PP-Recommendation.pdf.> Acesso em 30 de março de 2019.

O'NOLAN, G. \& REEVES, E. (2017). The nature of contracting hazards in public-private partnerships-Evidence from Ireland. International Journal of Public Administration, pp.

12. Doi:10.1080/01900692.2017.1373288 
OpARA, M. \& Rouse, P. (2018). The perceived efficacy of public-private partnerships: A study from Canada. Critical Perspectives on Accounting, Vol. 58, Num. 2, pp. 77-99. Doi: https://doi.org/10.1016/j.cpa.2018.04.004.

Osborne, S. P. (2000). Public-Private Partnerships: Theory and practice in international perspective. London: Routledge.

REICH, M. R. (2018). The core roles of transparency and accountability in the governance of global health Public-Private Partnerships. Health Systems, Reform, 00 pp. 110. Doi: https://doi.org/10.1080/23288604.2018.1465880

REYNAERS, A. M. \& GRIMMELIKHUIJSE, S. (2015). Transparency in public-private partnerships: Not so bad after all? Public Administration, Vol. 93, Num. 3, pp. 609-626. Doi: https://doi.org/doi:10.1111/padm.12142.

Reynaers, A. M. \& GraAf, G. (2014). Public Values in Public-Private Partnerships. International Journal of Public Administration, Vol. 37, Num. 2, pp. 120-128. Doi: https://doi.org/10.1080/01900692.2013.836665.

RUFIN, C. \& RiverA-SANTOS. (2012). Between commonweal and competition: Understanding the governance of Public-Private Partnerships. Journal of Management, Vol. 38, Num 5, pp. 1634-1654.

Doi:

https://doi.org/10.1177/0149206310373948.

SAnTANDREA, M.; BAILEY, S.; \& GIORgINO, M. (2015). Value for money in UK healthcare public-private partnerships: A fragility perspective. Public Policy and Administration, Vol. 31, Num. 3, pp. 260-279; Doi: https://doi.org/10.1177/0952076715618003.

SEKHRI, N.; FEACHEM, R.; \& NI, A. (2011). Public-private integrated partnerships demonstrate the potential to improve health care access, quality, and efficiency. Health Affairs, Vol. 30, Num. 8, pp. 1498-1507. Doi: https://doi.org/10.1377/hlthaff.2010.0461.

SIEMIATYCKI, M. \& FAROOQI, N. (2012). Value for Money and Risk in Public-Private Partnerships. Journal of the American Planning Association, Vol. 79, Num. 3, pp. 286-29. Doi: https://doi.org/10.1080/01944363.2012.715525.

SKELCHER, C. (2010). Governance of publicprivate partnerships. In: Hodge G.; Greve C.; \&
Boardman, A. (Eds.). International handbook on public-private partnerships. (pp. 292-304). Cheltenham, UK: Edward Elgar.

Shaoul, J.; Stafford, A.; \& Stapleton, P. (2010). Financial black holes: The disclosure and transparency of privately financed roads in the UK. Accounting, Auditing and Accountability Journal, Vol. 23, Num. 2, pp. 229-255. Doi: https://doi.org/10.1108/09513571011023200.

Souza, M. T.; Silva, M. D.; \& Carvalho, R. (2010). Revisão integrativa: O que é e como fazer. Einstein, Vol. 8, Num. 1, pp. 1-5. Doi: http://dx.doi.org/10.1590/s167945082010rw1134.

Steijn, B.; Klijn, E. K.; \& Edelenbos, J. (2011). Public private partnerships: Added value by organizational form or management? Public Administration, Vol. 89, Num. 4, pp. 1235-1252. Doi: $\quad$ https://doi.org/10.1111/j.14679299.2010.01877.x.

SNYDER, H. (2019). Literature review as a research methodology: An overview and guidelines. Journal of Business Research, Vol. 104, pp. 333-339. Doi: https://doi.org/10.1016/j.jbusres.2019.07.039.

TORChiA, M. \& CALABRo, A. (2018). Increasing the governance standards of Public-Private Partnerships in healthcare. Evidence from Italy. Public Organization Review, Vol. 18, Num. 1, pp. 93-110. Doi: https://doi.org/10.1007/s11115-016-0363-1.

TORChIA, M.; CALABrò, A. \& Morner, M. (2015). Public-Private Partnerships in the health care sector: A systematic review of the literature. Public Management Review, Vol. 17, Num. 2, pp. 236-261. Doi: https://doi.or/10.1080/14719037.2013.792380.

UNECE. (2008). Guidebook on promoting good governance in Public-Private Partnership. United Nations Economic Commission for Europe. Disponível em: https://www.unece.org/fileadmin/DAM/ceci/pu blications/ppp.pdf. Acesso em 30 de junho de 2019.

United NATIONS. (2019). Guiding principles on people-first Public-Private Partnerships in support of the United Nations Sustainable Development Goals. Economic Commission for Europe. Committee on Innovation, Competitiveness and Public-Private 
Partnerships. Working Party on Public-Private Partnerships. Disponível em:https://www.unece.org/fileadmin/DAM/ceci /documents/2018/PPP/WP/ECE_CECI WP PP P_2018_03-en.pdf. Acesso em 30 de junho de 2019.

ZAATO, J. J. \& HUdON, P. A. (2015). Governance lessons from public-private partnerships: examining two cases in the Greater Ottawa Region. Commonwealth Journal of Local Governance. Doi: https://doi.org/10.5130/cjlg.v0i0.4484.

WARSEN, R.; NEDERHAND, J.; KLIJN, E. H.; GROTENBREG, S.; \& KoPPENJAN, J. (2018). What makes public-private partnerships work? Survey research into the outcomes and the quality of cooperation in PPPs. Public Management Review, Vol. 20, Num. 8, pp, 1165-1185. Doi: https://doi.org/10.1080/14719037.2018.1428415

WARSEN, R.; KLIJN, E. H.; \& KOPPENJAN, J. (2019). Mix and Match: How Contractual and Relational Conditions Are Combined in Successful Public-Private Partnerships. Journal of Public Administration Research and Theory. Doi: 10.1093/jopart/muy082.

Williamson, O. E. (1979). Transaction-Cost economics: The governance of contractual relations. The Journal of Law and Economics, Vol. 22, Num. 2, pp. 233-261. https://doi.org/10.1086/466942.

Williamson, O. E. (1981). The Economics of Organization: The Transaction Cost Approach. American Journal of Sociology. Vol. 87, Num. 3, pp. 548-77.

\section{Nyalle Barboza Matos}

https://orcid.org/0000-0002-5006-661X.

$\mathrm{PhD}$. candidate in Accounting at the University of Brasilia, Brazil. Assistant Professor at the Amazonas State University - UEA.

E-mail: nyallematos@hotmail.com

\section{Andréa de Oliveira Gonçalves}

http://orcid.org/0000-0001-7514-8139.

Ph.D. in Latin American Integration from the University of São Paulo, Brazil. Associate professor at the University of Brasília - UnB

E-mail: andreaegoncalves@gmail.com
Williamson, O. E. (1985). Assessing Contract. Journal of Law, Economics, and Organization Vol. 1, Num. 2 pp. 177-208.

Williamson, O. E. (1999). Public and Private Bureaucracies: A Transaction Cost Economics Perspective. Journal of Law, Economics, \& Organization, Vol. 15, Num. 1, pp. 306-342.

Williamson, O. E. (2005). The economics of governance. American Economic Review, Vol. 95, Num. 2, pp. 1-18. Doi: https://doi.org/10.1257/000282805774669880.

WORLD BANK. (2013). Disclosure of project and contract information in Public-Private Partnerships. World Bank Institute. Disponível em:

<http://documents.worldbank.org/curated/pt/190 901468159906133/pdf/762780WP0Box370osur e0of0Project0PPP.pdf.> Acesso em: 3 de abril de 2019.

WORLD BANK. (2019). Guidance on PPP Contractual Provisions. World Bank Institute. Disponível em: https://ppp.worldbank.org/public-privatepartnership/library/guidance-ppp-contractualprovisions-2019.

XIOng, W.; Chen, B.; Wang, H.; \& ZHU, D. (2018). Governing public-private partnerships: A systematic review of case study literature. Australian Journal of Public Administration, Vol. $\quad 0, \quad$ pp. 1-18. Doi: https://doi.org/10.1111/1467-8500.12343. 